\title{
Soil water availability influences major ecosystem processes in tropical dry forest
}

\begin{abstract}
Tropical dry forests experience a long annual dry season therefore soil moisture availability is the predominant determining factor for the ecosystem processes in such forest types. The seasonal rainfall gradients and the availability of soil moisture have been observed to be highly associated with the distribution, diversity and primary productivity of plant communities in tropical dry forest. The soil moisture availability exhibits significant spatial heterogeneity which is responsible for the interspecific differences in the important components of resource use strategies, like leaf phenology and the function of water conducting xylem tissues. We observed seasonal variation in the soil water availability in tropical dry forest located in Vindhyan highlands, India. The results indicated significant seasonal and site wise variations in soil moisture content. We suggest that for proper management of the tropical dry forest vegetation, it is necessary to understand the major ecosystem processes influenced by the soil moisture conditions.
\end{abstract}

Keywords: tropical dry forest, soil moisture content, resource use strategies, phenology
Volume 2 Issue I - 2018

\author{
Chaturvedi RK,' Raghubanshi AS ${ }^{2}$ \\ 'Community Ecology and Conservation Group, Center for \\ Integrative Conversation, Xishuangbanna Tropical Botanical \\ Garden, Chinese Academy of Sciences, China \\ 2Institute of Environment and Sustainable Development, Banaras \\ Hindu University, India
}

\begin{abstract}
Correspondence: Chaturvedi RK, Community Ecology and Conservation Group, Center for Integrative Conversation, Xishuangbanna Tropical Botanical Garden, Chinese Academy of Sciences, Chinese Academy of Sciences, Menglun, Mengla, Yunnan 666303, China, Tel +86 I8288059250,

Email ravikantchaturvedil0@gmail.com
\end{abstract}

Received: November 02, 2017| Published: January 09, 2018

\section{Introduction}

Variation in soil moisture content (SMC) and nutrient availability leads to significant changes in the structure and function of the forest ecosystems. ${ }^{1,2}$ The seasonal rainfall gradients and the availability of soil moisture have been observed to be highly associated with the distribution, diversity and primary productivity of plant communities in tropical dry forest. ${ }^{3-15}$ Tropical dry forests are the predominant type of vegetation and globally represent second most important tropical forest; the diversity of various kinds of life forms in these ecosystems is considered to be highly influenced with water and nutrient availability. ${ }^{16}$ Along with a long annual dry period, disturbances such as browsing by domestic cattles and harvesting by humans usually results in an immediate decline in biodiversity and the associated process of regeneration. ${ }^{17-19}$ In tropical dry forests, the soil moisture availability exhibits significant spatial heterogeneity which is responsible for the interspecific differences in the important components of resource use strategies, like leaf phenology and the function of water conducting xylem tissues. ${ }^{20}$ Water accumulated in the tree stem, or stored in the subsoil, buffers the harmful effect of low water availability and helps in the flushing of new leaves during the long dry season. ${ }^{21-25}$ This suggests that tree water status, is probably the predominant determining factor for the phenology of trees, rather than any other climatic factor in the tropical dry forests. Borchert \& Rivera ${ }^{26}$ have observed that in majority of tree species of semi-deciduous tropical forests, leaf buds usually remain dormant for a long period during the dry season and bud-break is induced when there is increase in photoperiod after the arrival of spring equinox. Bud-break has been observed to be highly synchronous in the conspecific, 'spring-flushing' tree species, although few differences within species have also been reported. ${ }^{27}$ It has been reported that the dry season bud-break and leaf expansion in trees occurs only when they are fully rehydrated, ${ }^{23-28}$ and the shoot growth rate and the leaf expansion period varies according to differences in the availability of water. $^{24-26}$ To observe seasonal variation in the soil water availability in tropical dry forest, we selected five forest sites in Vindhyan highlands, India $\left(24^{\circ} 18^{\prime} 07^{\prime \prime}-25^{\circ} 00^{\prime} 17^{\prime \prime} \mathrm{N}, 82^{\circ} 37^{\prime} 38^{\prime \prime}-83^{\circ} 23^{\prime} 05^{\prime \prime} \mathrm{E}\right)$. The forest region experiences tropical monsoon climate with three seasons in a year, viz., summer (April-mid June), rainy (mid JuneSeptember) and winter (November-February). The site selection was done in a way that they represented a range density of trees and canopy openness. ${ }^{13}$ The measurement of soil moisture content (SMC) was done at 90 locations, randomly at each site, as percentage by volume every month, at a depth of $10 \mathrm{~cm}$ at 1-month intervals for 2 years (i.e. January 2005 to December 2006) using a theta probe instrument (type ML 1, Delta-T Devices, Cambridge, UK). The result of the study showed that across the 12 months in a year, SMC in July and August was higher at all five sites (Figure 1). Lower SMC was observed in November and December. The site wise variation in SMC was not significant only in July, August and September, when the availability of soil water was in plenty. During the dry months site-wise variation in SMC was high, probably due to differences in the water holding capacity of the forest sites.

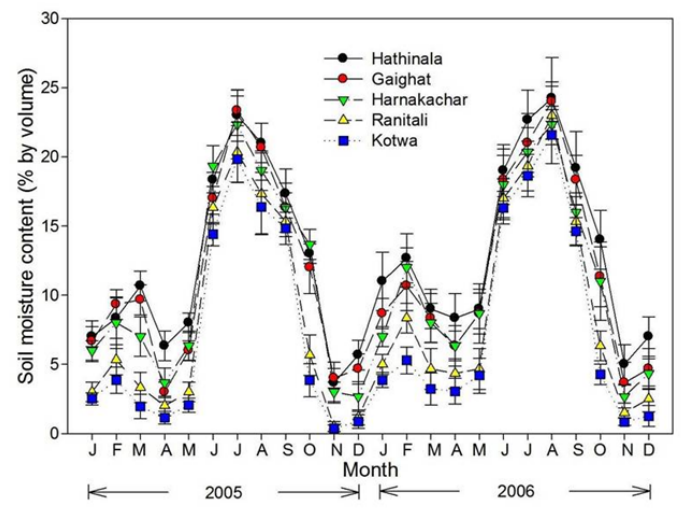

Figure I Monthly soil moisture content at the five study sites from January 2005 to December 2006. (Source). ${ }^{26}$ 


\section{Conclusion}

Tropical dry forests experience a long annual dry season therefore soil moisture availability is the predominant determining factor for the ecosystem processes in such forest types. For surviving in the water limited environment plants possess various kinds of strategies to make the most efficient use of water. Due to wide spatial heterogeneity in the soil moisture availability, plants exhibit interspecific differences in the resource use strategies. Therefore, for proper management of the tropical dry forest vegetation, it is necessary to understand the major ecosystem processes influenced by the soil moisture conditions.

\section{Acknowledgements}

RKC thanks Council of Scientific and Industrial Research, India (Award no. 09/13(452)/2012-EMR-I) and Natural Science Foundation of China (NSFC), Chinese Academy of Science, China (Grant No. 31750110466) for financial support

\section{Conflict of interest}

Authors declare there is no conflict of interest in publishing the article.

\section{References}

1. Campo J, Maass M, Jaramillo V, et al. Phosphorus cycling in a Mexican tropical dry forest ecosystem. Biogeochemistry. 2001;53(2):161-179.

2. Chaturvedi RK. Plant functional traits in dry deciduous forests of India. Banaras Hindu University, India; 2010. p. 1-252.

3. Lieth $H$. Primary production of the major vegetation units of the world In: Lieth $\mathrm{H}$ and Whittaker $\mathrm{RH}$, editors. Primary productivity of the biosphere. Springer, USA; 1975. p. 203-231.

4. Boyer JS. Plant productivity and environment. Science. 1982;218(4571):443-448.

5. Currie DJ, Paquin V. Largescale biogeographical patterns of species richness of trees. Nature. 1987;329:326-327.

6. OBrien EM. Climatic gradients in woody plant species richness: towards an explanation based on an analysis of southern Africa's woody flora Journal of Biogeography. 1993;20(2):181-198.

7. Chaturvedi RK, Raghubanshi AS, Singh JS. Carbon density and accumulation in woody species of tropical dry forest in India. Forest Ecology and Management. 2011a;262(8):1576-1588.

8. Chaturvedi RK, Raghubanshi AS, Singh JS. Leaf attributes and tree growth in a tropical dry forest. Journal of Vegetation Science. 2011b;22(5):917-931.

9. Chaturvedi RK, Raghubanshi AS, Singh JS. Plant functional traits with particular reference to dry deciduous forests: a review. Journal of Biosciences. 2011c;36(5):963-981.

10. Chaturvedi RK, Raghubanshi AS, Singh JS. Effect of small scale variations in environmental factors on the distribution of woody species in tropical deciduous forests of Vindhyan Highlands, India. Journal of Botany. 2011d;2011:1-10.

11. Chaturvedi RK, Raghubanshi AS, Singh JS. Growth of tree seedlings in a dry tropical forest in relation to soil moisture and leaf traits. Journal of Plant Ecology. 2013;6(2):158-170.
12. Chaturvedi RK, Raghubanshi AS, Singh JS. Relative effects of different leaf attributes on sapling growth in tropical dry forest. Journal of Plant Ecology. 2014;7(6):544-558.

13. Chaturvedi RK, Raghubanshi AS.Species Composition, Distribution and Diversity of Woody Species in tropical dry forest of India. Journal of Sustainable Forestry. 2014;33(8): 729-756.

14. Chaturvedi RK, Raghubanshi AS. Assessment of carbon density and accumulation in mono- and multi-specific stands in Teak and Sal forests of a tropical dry region in India. Forest Ecology and Management. 2015;339:11-21.

15. Gaviria J, Turner BL, Engelbrecht BMJ. Drivers of tree species distribution across a tropical rainfall gradient. Ecosphere. 2017;8(2):e01712.

16. Medina E. Diversity of life forms of higher plants in neotropical dry forest. In: Bullock H, Mooney HA, Medina E (Eds.), Seasonally dry tropical forests. Cambridge University Press, UK; 1995. p. 221- 242.

17. Chaturvedi RK, Raghubanshi AS, Singh JS. Effect of grazing and harvesting on diversity, recruitment and carbon accumulation of juvenile trees in tropical dry forests. Forest Ecology and Management. 2012;284(2012):152-162.

18. Chaturvedi RK, Raghubanshi AS, Singh JS. Sapling harvest: A predominant factor affecting future composition of tropical dry forests. Forest Ecology and Management. 2017a;384:221-235.

19. Chaturvedi RK, Raghubanshi AS, Tomlinson KW, et al. Impacts of human disturbance in tropical dry forests increase with soil moisture stress. Journal of Vegetation Science. 2017b;28(5):997-1007.

20. Mendez AR, Pineda GF, Paz H, et al. Leaf phenology is associated with soil water availability and xylem traits in a tropical dry forest. Trees. 2013;27(3):745-754.

21. Borchert R. Phenology and ecophysiology of tropical trees: Erythrina poeppigiana OF. Cook. Ecology. 1980;61(5):1065-1074.

22. Borchert R. Phenology and control of flowering in tropical trees. Biotropica. 1983;15(2):81-89.

23. Borchert R. Soil and stem water storage determine phenology and distribution of tropical dry forest trees. Ecology. 1994a;75(5):1437-1449.

24. Borchert R. Water status and development of tropical trees during seasonal drought. Trees-Structructure and Function. 1994b;8(3):115-125.

25. Reich PB, Borchert R. Water stress and tree phenology in a tropical dry forest in the lowlands of Costa Rica. Journal of Ecology. 1984;72(1):61-74.

26. Borchert R, Rivera G. Photoperiodic control of seasonal development and dormancy in tropical stem-succulent trees. Tree Physiology. $2001 ; 21(4): 213-221$.

27. Chaturvedi RK, Raghubanshi AS. Leaf life-span dynamics of woody species in tropical dry forests of India. Tropical Plant Research. 2016;3(1):199-212.

28. Borchert R, Rivera G, Hagnauer W. Modification of vegetative phenology in a tropical semi-deciduous forest by abnormal drought and rain. Biotropica. 2002;34(1):27-39. 